\title{
Nowy dyskurs o pograniczu dwóch światów
}

\author{
Bartosz Czepil ${ }^{1}$ \\ Link do artykułu: \\ http://pogranicze.uni.opole.pl/biblioteka/docs/tom2/czepil_t2n1.pdf
}

Standard cytowania (APA):

Czepil, B. (2014). Nowy dyskurs na pograniczu dwóch światów. Pogranicze. Polish Borderlands Studies, t. 2, nr 1, s. 114-120.

The EU-Russia Borderland. New context for regional cooperation, red. Heikki Eskelinen, Ilkka Liikanen, James W. Scott, Routledge 2012, 238 s.

Praca zbiorowa pod redakcją naukowców z Instytutu Karelii Uniwersytetu Finlandii Wschodniej stanowi interesujący, multidyscyplinarny wkład do badań, nie tylko nad problematyką pogranicza, ale także nad Rosją (przede wszystkim Rosją regionalną) oraz Unią Europejską. Książka wydana przez wydawnictwo Routledge w ramach serii Studiów nad Rosją i Europą Wschodnią, nie przez przypadek została przygotowana przez naukowców reprezentujących Uniwersytet Finlandii Wschodniej. Uniwersytet ten jest zlokalizowany na pograniczu fińsko-rosyjskim, w trzech miastach południowo-wschodniej Finlandii: Joensuu, Kuopio, Savonlinnie. Położenie geograficzne, a właściwie geopolityczne, tego ośrodka niejako predestynuje go do prowadzenia badań nad pograniczem fińsko-rosyjskim, które jednocześnie stanowi pogranicze Unii Europejskiej i Federacji Rosyjskiej.

Publikacja będąca efektem kilku projektów badawczych (Eskelinen, Liikanen, Scott 2012) porusza zagadnienia z zakresu geopolityki, stosunków międzynarodowych, ekonomii oraz geografii społecznej. Jak piszą we wstępie sami autorzy, wspólnym mianownikiem podejmowanych badań było przekonanie, że załamanie się zimnowojennego ładu geopolitycznego, wraz z wyraźnymi i przez długi czas trwałymi granicami między Wschodem a Zachodem, stworzyło warunki do ponownego przedefiniowania granic i pograniczy między tymi obszarami. Podniesienie „żelaznej kurtyny” oraz wejście Finlandii do Unii Europejskiej w 1995 roku oznaczało powstanie długiej na ponad 1300 km granicy między Unią Europejską a Rosją (do 2004 roku jedynej takiej granicy), a wraz z tym „zaaranżowanie” swego rodzaju naturalnego eksperymentu pozwalającego na obserwowanie transformacji obszarów pogranicza fińsko-rosyjskiego pod wpływem liberalizacji i europeizacji reżimu granicznego. Jednak po krótkim okresie lat dziewięćdziesiątych, gdy pojawiły się optymistyczne perspektywy na zbliżenie Rosji z europejskim modelem państwa (wyrazem tych tendencji była Umowa o Współpracy i Partnerstwie z 1997 roku), wraz z dojściem do władzy Władimira Putina, Rosja zaczyna definiować swoją tożsamość

1 Dr Bartosz Czepil - członek redakcji czasopisma „Pogranicze. Polish Borderlands Studies”. Współpracownik Fundacji Batorego, Instytutu Politologii Uniwersytetu Opolskiego i Transparency International. 
geopolityczną w opozycji do Unii Europejskiej, coraz częściej odwołując się do idei euroazjatyzmu (Euroazjatycka Unia Celna między Rosją, Kazachstanem i Białorusią jest tej idei realną manifestacją). Tak zarysowane zmiany geopolityczne nie pozostają bez wpływu na procesy regionalne i lokalne. Przedstawienie wielowymiarowego oddziaływania geopolitycznych zmian na mikrostrukturalne przekształcenia na pograniczu państw, kultur i cywilizacji należy niewątpliwe do podstawowych walorów tej pracy.

Publikacja skoncentrowana jest przede wszystkim na procesach zachodzących na styku południowo-wschodniej Finlandii i północno-zachodniej Rosji, traktowanym jako mikro-laboratorium relacji między Unią Europejską a Rosją, a nawet szerzej, jako symboliczne pogranicze między Zachodem a Wschodem. To tu ścierały się niegdyś interesy Szwecji i Carskiej Rosji oraz przenikały wpływy zachodniego i wschodniego chrześcijaństwa. W Helsinkach do dziś możemy zresztą podziwiać największą prawosławną świątynię na obszarze Unii Europejskiej. Tutaj też doszło do krwawej konfrontacji między zwolennikami państwa opartego na wspólnocie narodowej z tymi, którzy domagali się wspólnoty opartej na kryteriach klasowych. Wojna domowa w Finlandii roku 1918, wydarzenie właściwie niezakotwiczone $\mathrm{w}$ zbiorowej narracji o europejskich konfrontacjach ideologicznych XX wieku, pochłonęła około 30 tysięcy ofiar, w tym 25 tysięcy z obozu czerwonych (Jussila, Hentilä, Nevakivi 2001: 122). Na tym pograniczu przelewała się krew również podczas Wojny Zimowej lat 1939-1940, wojny przede wszystkim pozycyjnej, w której walczono o każdy skrawek Przesmyku Karelskiego. Fiński socjolog Risto Arapulo pisze, że ta specyficzna pozycja Finlandii, rozdarcie między Wschodem a Zachodem, jest wciąż fundamentem głębokich struktur fińskiej kultury politycznej, która charakteryzuje się uznaniem polityki kompromisu za adaptacyjną konieczność podyktowaną narzuconymi z zewnątrz ograniczeniami (Alapuro 2004: 98-99).

W książce znajdujemy 13 rozdziałów podzielonych na trzy części tematyczne: 1. Wpływ integracji politycznej w Federacji Rosyjskiej na regiony przygraniczne północno-zachodniej Rosji; 2. Wymiary i aktorzy interakcji na pograniczu fińsko-rosyjskim; 3. Północno-zachodnia Rosja jako obszar socjo-kulturowej transformacji. W pracy pojawia się zatem solidna dawka wiedzy na temat Rosji północno-zachodniej, jej specyfiki historycznej, kulturowej i ekonomiczno-politycznej. O wiele mniej znajdujemy natomiast informacji na temat wschodniej Finlandii. Potencjalnemu czytelnikowi rekomendowałbym zacząć lekturę od ostatniego z tekstów, który jest swoistego rodzaju podsumowaniem. Przede wszystkim znajdziemy tam zwięzłe, ale treściwe wprowadzenie do samej teorii „pogranicza”, w którym autorzy przedstawiają wielość sposobów rozumienia tej kategorii analitycznej, aby później zaaplikować ją do regionu Karelii jako serca pogranicza fińskorosyjskiego, które jest $\mathrm{w}$ centrum analiz w pozostałych częściach książki. Pozwoli to na zlokalizowanie konkretnych kwestii z pozostałych artykułów w bardziej ogólnej perspektywie teoretycznej, a także historyczno-instytucjonalnej, co ułatwia i pogłębia zrozumienie fenomenu granicy między Finlandią a Rosją. Karelia to kraina geograficzno-historyczna, rozpościerająca się na pograniczu fińsko-rosyjskim, której większa część, jako Republika Karelii, znalazła się w Rosji w wyniku rozstrzygnięć II wojny światowej. Fińska populacja zamieszkująca terytorium zdobyte przez Sowietów została przesiedlona do Finlandii, a na jej miejsce zjechali się Rosjanie w ramach sowietyzacji regionu. Do dziś kultura ludowa Karelii, jej mitologia i architektura są utożsamiane z fińskością, stanowiąc część pamięci zbiorowej Finów. Obecnie historyczna Karelia jest fundamentem Euroregionu Karelia, w skład którego wchodzi rosyjska Republika Karelii oraz fińskie: Północna Karelia, Północna Ostrobotnia 
oraz Kainuu. Euroregion rozciąga się wzdłuż 700 km granicy fińsko-rosyjskiej. Jak dowiadujemy się od autorów ostatniego z tekstów, Jamesa Scotta i Vladimira Klossova, liberalizacja reżimu granicznego po upadku ZSRR oraz wejście Finlandii do Unii Europejskiej istotnie zmieniły relacje między tymi sąsiadami. Od 1995 roku współpraca transgraniczna uzyskała wsparcie finansowe Unii Europejskiej, szczególnie w ramach programu Interreg i TACIS (Technical Assistance for the Commonwealth of Independent States). Unijnemu wsparciu towarzyszyło podporządkowanie fińskiej polityki współpracy transgranicznej zasadom wypracowanym na poziomie unijnym. Nastąpiło, między innymi, wzmocnienie samorządów regionalnych, które przejęły ciężar współpracy transgranicznej, a współpraca ta nabrała charakteru wspólnie realizowanych projektów. Dotyczyła m.in. takich obszarów jak edukacja, służba zdrowia, polityka społeczna i ochrona środowiska. Jak wynika z informacji zawartych w książce to strona fińska była głównym animatorem współpracy ze stroną rosyjską. Władze federalne Rosji raczej z rezerwą odnosiły się do współpracy transgranicznej i nie wykazywały większej aktywności, poza wsparciem budowy nowych przejść granicznych. O wiele większą aktywność wykazywały władze samorządowe zainteresowane stymulowaniem rozwoju gospodarczego. Tu szczególnie interesujące są studia przypadku współpracy transgranicznej mono-przemysłowych miast Swetogorska oraz Kostomukshy, autorstwa Dmitra Zimina, Juhy Kotilainena i Evgeni Prokhorovej. Pokazują one głęboką transformację małych, przygranicznych miast „jednej fabryki” pod wpływem zmiany funkcji granicy, jaka nastąpiła w wyniku procesów o zasięgu makropolitycznym.

Czytelnicy zainteresowani rozwojem gospodarczym na pograniczu powinni sięgnąć do tekstu Dmitry Zimina na temat zmian infrastruktury eksportowej rosyjskich surowców energetycznych. Autor zwraca uwagę jak strategia geopolityczna Moskwy oraz związana z nią polityka energetyczna wpływa na dynamikę ekonomiczną regionów pogranicza rosyjsko-fińskiego. Jest to optyka, do której nie przywykliśmy, gdy przedmiotem analizy jest polityka energetyczna i zagraniczna Rosji, zazwyczaj traktowana w kategoriach strategii globalnej. Jednak Zimin pokazuje jak wielka polityka, której towarzyszą, podyktowane względami strategicznymi inwestycje infrastrukturalne, może zmienić los gospodarek regionalnych. Chęć ominięcia krajów tranzytowych w Europie Wschodniej, przez które przepływają rosyjski gaz i ropa, skłoniły Moskwę do wielkich inwestycji infrastrukturalnych $\mathrm{w}$ miastach portowych obwodu leningradzkiego, które mają zabezpieczyć odmienny szlak transportu surowców naturalnych do Europy Zachodniej. Inwestycje w takich miastach jak Wyborg, Primorsk, Wysock (są to trzy najważniejsze porty rosyjskie w Zatoce Fińskiej) w ciągu kilku lat na przełomie XXI wieku doprowadziły do ekonomicznego rozkwitu obwodu leningradzkiego. W tym kontekście na uwagę zasługuje również tekst Heikkego Eskelina, w którym przeprowadza, między innymi, analizę zmian SanktPetersburga jako miasta o potencjale gospodarczym mającym istotny wpływ na rozwój fińskich regionów przygranicznych. Należy pamiętać, że metropolia Sankt-Petersburg ma więcej mieszkańców niż cała Finlandia. Duża część importu rosyjskiego jest transportowana przez Finlandię - miasta portowe oraz infrastruktura transportowa południowowschodniej Finlandii zawdzięczają swoją dynamikę importowi do północno-zachodniej Rosji, w tym Sankt-Petersburga.

Jedną z bardziej interesujących kwestii podkreślanych przez autorów jest analiza symbolicznego statusu granicy fińsko-rosyjskiej. Pertii Koistinen i Oxana Krutowa, w tekście na temat rynku pracy na omawianym pograniczu, twierdzą że granica fińsko-rosyjska charakteryzuje się swoistą wielopoziomowością i wysokim nasyceniem polityczności. 
Dla Rosjan jest to granica, poza którą rozpościera się nie tylko Finlandia, ale także takie struktury ponadnarodowe jak wspólnota nordycka oraz Unia Europejska. Jest to granica z szeroko pojmowanym Zachodem. Natomiast z punktu widzenia Finów granica ta jest ściśle związana z kwestią tożsamości narodowej - jest to ważny punkt odniesienia dla wyobrażeń o własnej wspólnocie narodowej, która od czasów Wielkiego Księstwa Fińskiego była wzmacniana na zasadzie opozycji do dominującego Imperium Rosyjskiego. Na kolejny ważny aspekt granicy zwraca uwagę Matti Fritsch, który analizuje transgraniczną współpracę regionalną $\mathrm{w}$ zakresie planowania przestrzennego. Badacz wskazuje, że wejście Finlandii do Unii przesunęło punkt ciężkości w zakresie transgranicznego planowania przestrzennego na fińskie samorządy. Jednocześnie, wraz z dojściem Putina do władzy, zmienił się klimat po stronie rosyjskiej i reformy instytucjonalne ograniczyły niezależność rosyjskich regionów w zakresie planowania przestrzennego. Wobec tego transgraniczna współpraca w zakresie planowania przestrzennego jest słaba. Dodatkowo Fritsch wyjaśnia ten brak współpracy bardziej ogólnymi przyczynami, mianowicie geopolityczną wrażliwością wszelkich przejawów transgranicznej polityki planowania przestrzennego, ponieważ siłą rzeczy taka polityka dotyka kwestii kontroli przestrzeni, suwerenności narodowej i integralności terytorialnej. Tu przestrzeń staje się terytorium - kategorią stricte polityczną, ponieważ terytorium to przestrzeń pod kontrolą suwerennej władzy państwa. Ta uniwersalna geopolityczna wrażliwość polityki planowania przestrzennego ulega wzmocnieniu w przypadku pogranicza fińsko-rosyjskiego - terytorium będącego przedmiotem walki między Finlandią a Związkiem Radzieckim, którego część została odebrana Finlandii i wciąż pozostaje pod kontrolą Rosji.

Należałoby przywołać jeszcze jeden poznawczy walor pracy na temat pogranicza Unii Europejskiej i Rosji, wyraźnie wyartykułowany przez niektórych autorów. Matti Fritsch przypomina nam, że jest to terytorium, na którym zderzają się dwie filozofie funkcjonowania Unii Europejskiej. Pierwsza to ta wewnętrzna, charakteryzująca się prointegracyjnym podejściem, gdzie akcent pada przede wszystkim na zanikanie granic międzypaństwowych oraz redukowanie regionalnych dysproporcji rozwoju społeczno-ekonomicznego. Druga filozofia, której często nie doświadczają mieszkańcy żyjący w unijnym „interiorze”, dlatego też jest mniej obecna w świadomości Europejczyków, to filozofia działania granic zewnętrznych Wspólnoty Europejskiej. Tu można doświadczyć klimatu ekskluzji i ochrony przed Innym. Taki klimat skłania do myślenia o granicy raczej w kategoriach strategicznego bezpieczeństwa, niż kooperacji. W tej optyce granica jawi się nie jako przestrzeń spotkania, ale jako obszar kontroli, podziałów i wykluczenia. Dlatego należy pamiętać o obserwacjach Pertii Koistinena i Oxany Krutowej, według których koncepcje nieskrępowanego przepływu siły roboczej, mające rzekomo opisywać współczesną zglobalizowaną gospodarkę, nie znajdują potwierdzenia w świetle doświadczeń granicy fińsko-rosyjskiej - tu nadal państwo narodowe odgrywa podstawową rolę regulatora przepływów ludzi w celach zarobkowych. Obszar pogranicza fińsko-rosyjskiego uświadamia nam także, że tezy o stopniowym zaniku granic są ufundowane na wąskim, de facto europocentrycznym, doświadczeniu integracji ponadnarodowej, które w perspektywie doświadczeń wschodnich rubieży Unii Europejskiej nie wytrzymują krytyki. Na ten schizofreniczny dualizm Europy, która z jednej strony domaga się odrzucenia granic terytorialnych, jednocześnie jednak zażarcie broni swojego terytorium, wskazuje pośrednio Zygmunt Bauman w swojej książce „Europa niedokończona przygoda”. Bauman pisze w niej o istocie 
Europy i europejskości, jako oderwanej od swoich terytorialnych fundamentów, eksterytorialności, która „drwi sobie z wszelkich przestrzennych więzów i barier”. Dalej filozof tak rozwija swą myśl:

Drażniąca eteryczność i uporczywa eksterytorialność tej „istoty” podkopuje i podmywa stabilną terytorialność europejskich realiów. Geograficzna Europa nigdy nie miała ustalonych granic i wątpliwe, aby mogła się ich doczekać, dopóki jej „istota” będzie, tak jak dotychczas, „swobodna” i jedynie luźno, jeśli w ogóle związana z jakimś konkretnym miejscem w przestrzeni. Ilekroć państwa europejskie próbują wytyczyć wspólnie granice kontynentu, zatrudniając do ich strzeżenia uzbrojonych po zęby strażników, urzędników imigracyjnych i służby celne, tylekroć stwierdzają, że nie są w stanie zapewnić im szczelności i sprawić, by stały się nieprzenikalne. Każda granica otaczająca Europę będzie zawsze wyzwaniem dla reszty planety i zaproszeniem do jej sforsowania (Bauman 2005: 13).

Ta myśl Baumana oraz refleksje nad pograniczem fińsko-rosyjskim uświadamiają nam jednostronność pojmowania Europy jako przestrzeni bez granic, przypominając jednocześnie o świecie poza Europą - świecie oddzielonym zewnętrzną granicą od ekskluzywnej twierdzy, jaką jest Unia Europejska.

$\mathrm{W}$ jednym $\mathrm{z}$ kluczowych tekstów na temat teorii granic w dobie postmodernizmu Anssi Paasi (de facto również badacz pogranicza fińsko-rosyjskiego) oraz David Newman, wskazują, że wszelkie granice są tworem dyskursywnym tzn. są konstruowane poprzez najróżniejsze narracje zbiorowe, które ostatecznie określają specyfikę i status danej granicy, również państwowej (Newman, Paasi 2013). Podział na „my”„oni”, któremu towarzyszy wyobrażenie granicy oraz określony ładunek emocjonalny, jest tworzony w procesie socjalizacji terytorialnej wprowadzającej w świat wyobrażeń o terytoriach, które "należą do nas”, w ten sposób legitymizując istniejące podziały kulturowo-polityczne oraz odwiecznych wrogów i oddanych przyjaciół. Jak pisze Paasi, $\mathrm{w}$ proces konstruowania narracji o granicach zaangażowanych jest szereg instytucji, w tym edukacyjnych, a materiały edukacyjne takie jak atlasy czy podręczniki do geografii i historii pozwalają na dekonstrukcję ukrytych w nich narracji dotyczących granic. Pojawia się więc pytanie: jaką narrację o pograniczu Unii Europejskiej-Rosji proponują autorzy omawianej tu publikacji? Trzeba zaznaczyć, że zamysł redaktorów został w tej mierze wyraźnie wyartykułowany już we wstępie (oraz podtytule samej książki „nowy kontekst dla współpracy regionalnej”), gdzie wyraźnie zaznaczyli, że doświadczenia pogranicza fińsko-rosyjskiego nie mogą być rozumiane w kategoriach „prostej geopolitycznej dychotomii", a samo przekonanie o nieusuwalnych ograniczeniach dla integracji między Unią Europejską a Rosją jest zakotwiczone raczej w „myśleniu geopolitycznym", niż analizie relacji na pograniczu. Co więcej, w ostatnim tekście James Scott i Vladimir Kolossov twierdzą, że tradycyjna geopolityczna narracja podziału cywilizacyjnego Wschód-Zachód i towarzysząca jej retoryka zagrożenia bezpieczeństwa są barierą dla polepszenia wzajemnych relacji. Według nich, bliższe spojrzenie, właśnie na pogranicze fińsko-rosyjskie, dostarcza empirycznych fundamentów dla narracji odwołującej się do dialogu i kooperacji. Wyraźną intencją tego międzynarodowego teamu naukowców, wywodzących się zresztą ze Wschodu i Zachodu, jest stworzenie narracji dialogicznej i kooperacyjnej. Myślę, że plan został zrealizowany, jednak może pozostawić pewien dysonans oraz konfuzję, szczególnie u polskiego czytelnika (a być 
może tylko u jednego z nich czyli autora tekstu). Obraz relacji Rosja-Finlandia, jaki wyłania się z 13 tekstów, nie wpisuje się w dychotomiczną strukturę opisującą konfrontację dwóch odmiennych modeli polityczno-ekonomicznych i kulturowych. Autorom wyraźnie udało się uniknąć wartościowania, a szczególnie negatywnych konotacji związanych z opisem rosyjskiej polityki, być może ze względu na fakt, że praca jest owocem współpracy fińskich i rosyjskich badaczy. Jest to perspektywa kwestii rosyjskich w dużej mierze obca polskiemu odbiorcy - wolna od stereotypów i wartościowania, ale również od faktów, które mogłyby stanowić ważne tło dla zrozumienia i oceny relacji między Rosją i Unią Europejską. Autorzy uwolnili się od dyskursu o Rosji jako państwie autorytarnym - w całej książce słowo „authoritarian” na określenie rosyjskiego systemu politycznego pojawia się tylko raz (na s. 48). Natomiast pojęcie „finlandyzacji”, tak mocno zakotwiczone w polskiej narracji o Zimnej Wojnie, w ogóle się w książce nie pojawia, chociaż autorzy piszą o dużym wpływie Związku Radzieckiego na fińską politykę zagraniczną i wewnętrzną $\mathrm{w}$ ostatnim $\mathrm{z}$ tekstów. Jest to w pewnym sensie zaletą tej pracy, która jest przecież pracą stricte naukową, w związku z tym napisaną w zgodzie z ideą elementarnej neutralności aksjologicznej. Jednak, zdaniem autora, ten brak wyartykułowania odmiennych cech reżimu politycznego Rosji oraz państw unijnych (pogranicze państwa demokratycznego i autorytarnego) jawi się jako pewna luka, szczególnie w kontekście najświeższych wydarzeń międzynarodowych, których centrum jest Ukraina i Krym. Dla osoby niezaznajomionej z realiami współczesnej Rosji, obraz Rosji, jaki mogłaby ona odtworzyć po lekturze tej publikacji nie ma wiele wspólnego z autorytaryzmem refleksja nad aksjologicznymi fundamentami sprawowania władzy została tu właściwie wyparta. Natomiast czytelnik pozbawiony wiedzy o „finlandyzacji”, może dojść do przekonania, że Finlandia w dobie Zimnej Wojny była w pełni suwerennym państwem zaangażowanym po stronie Zachodu. To wrażanie jest jeszcze bardziej wzmocnione, gdy w jednym z tekstów czytamy, że „historycznie rzecz ujmując, rosyjsko-fińskie relacje zawsze charakteryzowały się pozytywną postawą i brakiem konfliktów" (Belokurova i Nozhenko 2012: 37). Czy jest to ignorancja spychająca w zapomnienie czasy dominacji Imperium Cara, agresję Stalina w roku 1940 oraz okres finlandyzacji? A może dominacja polityczna silniejszego nad słabszym, powoduje, że ten pierwszy utożsamia narzucony kompromis z brakiem konfliktów.

Trudno więc oprzeć się wrażeniu, że neutralność poznawcza badaczy jawi się jako neutralność podyktowana nie tylko empiryzmem, ale także idealizmem wynikającym z pragnienia tworzenia nowego pro-kooperacyjnego dyskursu. Książka z pewnością jest dobrym przykładem tego jak o drażliwych sprawach pisać bez wyraźnego wartościowania. Zaletą tej aksjologicznej pustki jest uświadomienie sobie zinternalizowanych „narracji o granicach” składających się na polską wyobraźnię geopolityczną. Tam gdzie dla mnie, na poziomie wyobrażeniowym, następuje przejście od świata demokratycznego do świata autorytarnej Rosji - przejście wyobrażone jako jakościowy, normatywny przeskok między demokracją a autorytaryzmem, dla autorów omawianej pracy taka przepaść wydaje się nie istnieć. 


\section{Literatura:}

- Alapuro, R. (2005). What is western and what is eastern in Finland. Thesis Eleven, nr 77.

- Bauman, Z. (2005). Europa niedokończona przygoda. Kraków: Wydawnictwo Literackie.

- Belokurova, E., Nozhenko, M. (2012). Regional community-building and cross-border interaction. W: H. Eskelinen, I. Liikanen, J.W. Scott (red.), The EU-Russia Borderland. New context for regional cooperation. Oksford Nowy Jork: Routledge.

- Eskelinen, H., Liikanen, I., Scott, J.W. (red.). (2012). The EU-Russia Borderland. New context for regional cooperation. Oksford Nowy Jork: Routledge.

- Jussila, O., Hentilä, S., Nevakivi, J. (2001). Historia polityczna Finlandii 1809-1999. Kraków: Universitas.

- Newman, D., Paasi, A. (2013). Podziały i sąsiedztwa w postmodernistycznym świecie. Narracje granic w geografii politycznej. Pogranicze. Polish Borderlands Studies, $n r 1$, s. 1234 . 